\title{
STUDY ON THE PROPERTIES OF SEMI-SYNTHETIC MOTOR OIL CASTROL 10W-40 AFTER USE IN A DIESEL ENGINE
}

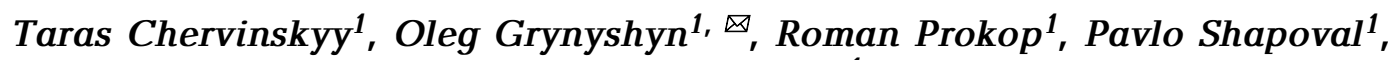 \\ Bohdan Korchak ${ }^{1}$
}

https://doi.org/10.23939/chcht15.03.432

\begin{abstract}
The changes in operational and physicochemical properties of original and used semi-synthetic motor oil Castrol 10W-40 before and after its use in a diesel engine have been investigated. Derivatographic studies were carried out to examine a thermal stability; IR spectroscopy was used to confirm the presence of oil aging products. The composition of the inorganic part of the studied semi-synthetic oils was established by X-ray fluorescence analysis.
\end{abstract}

Keywords: semi-synthetic motor oil, used oil, thermal decomposition, oil aging, X-ray fluorescence analysis, IR spectroscopy.

\section{Introduction}

The full functioning of many branches of domestic industry and agriculture is impossible without the use of lubricating oils, lubricants, coolants, etc. Today, more than 42 million tons of various lubricants per year are produced in the world. In Ukraine their total production increases annually by $20 \%$.

The main consumers of lubricating oils are machine-building and automobile industries; automobile, railway, aviation and sea transport; fuel and energy complex, etc. The traditional basis of these products is mineral oils, the amount of which varies within 96-98\%. However, despite a low cost of mineral lubricating oils, they have a number of negative properties, in particular, low biodegradability, relatively high toxicity, limited shelf life and so on.

Nowadays, at the time of rapid development, renewal and improvement of many sectors of the economy, the task of creating and improving highly biodegradable lubricating materials is becoming increasingly important. One of the ways to produce environmentally friendly

\footnotetext{
${ }^{1}$ Lviv Polytechnic National University,

12 Bandery St., Lviv 79013, Ukraine

ogrynyshyn@ukr.net

(c) Chervinskyy T., Grynyshyn O., Prokop R., Shapoval P., Korchak B., 2021
}

lubricants is to create new and improve existing formulations of semi-synthetic and synthetic motor oils with a long service life due to the addition of synthetic and polymeric materials. This solution of the long-term problem allows to release a significant part of the mineral base of lubricating oils, to increase their service life in internal combustion engines (ICE) and to increase significantly the service life of ICE.

During operation in ICE the motor oils undergo significant changes: water flooding, contamination with mechanical impurities and residues of unburned fuel, changes in chemical composition, etc. The composition of used motor oils includes pollutants, decomposition products of additives, heavy metals and acids, products of oil thermal decomposition, products of various chemical transformations of oil hydrocarbon part, etc. The toxicity of used oils (UO) is increased with the increase of molecular weight, acid value (AI), as well as the content of arenes, asphaltresinous substances and sulfur compounds. More than 140 carcinogenic compounds have been identified in UO, in particular, benzo $(\alpha)$ pyrene, phenantrene, etc. The amount of these hazardous compounds increases with increasing service life of engine oil in ICE and negatively affects the environment and public health. The combination of the processes, which leads to the deterioration of the operational properties of motor oil, is called the oil aging. However, despite numerous studies the essence of this phenomenon remains controversial and not fully understood.

Previously [1] we investigated the changes in the operational properties of mineral motor oil before and after its operation in the diesel engine of agricultural machinery. The thermal stability of original and used diesel engine oil was studied by the derivatography, the inorganic composition of these oils was determined by $\mathrm{X}$ ray fluorescence analysis, and the presence of thermocatalytic and destructive products was confirmed by IR spectroscopy. The authors explained the phenomenon of mineral oil aging in diesel engines on the basis of experimental results, which are in agreement with those of other authors [2-9].

To date, semi-synthetic motor oils are one of the most popular groups of oils used in diesel engines of 
regional and international vehicles (commercial class). Due to the lack of attention paid to the study of aging processes of such motor oils, they were selected as the object of research. The study on changes in their properties after using in ICE will establish the probable causes and mechanism of oil aging. At the same time, the obtained results will be used to select the optimal regeneration technology for used semi-synthetic motor oils (USSO).

So, the purpose of this work is to study the change in performance of original and used semi-synthetic motor oil Castrol 10W-40, their thermal stability, changes in the inorganic part, search and confirmation of the presence of primary aging products in the used oil.

\section{Experimental}

Original semi-synthetic motor oil Castrol 10W-40, which is widely used in diesel engines of commercial vehicles, and used oil of the same brand, which was drained from the crankcase of the diesel engine after its standard service life, were selected as the initial objects of research.

The densities of the above oils were determined by the pycnometric method, the viscosity - by the viscometric method; the refractive index was determined using a refractometer, and the flash point - using an open cup device.

Studies of oil thermal stability were performed on the Q-1500D derivatograph of Paulik-Paulik-Erdey system with the registration of the analytical signal of weight loss and thermal effects using a computer. The samples were analyzed in a dynamic mode with a heating rate of $10 \mathrm{deg} / \mathrm{min}$ in the air. The weight of the samples was $100 \mathrm{mg}$. The reference substance was aluminum oxide.

To determine the elemental composition of oils the $\mathrm{X}$-ray fluorescence spectral analysis was performed on a mobile precision analyzer EXPERT $3 \mathrm{~L}$, designed to determine the mass fraction of chemical elements in homogeneous monolithic and powdery objects. Oil samples for the analysis were burned at $723 \mathrm{~K}$ for $4 \mathrm{~h}$, cooled in a desiccator and ground to a powder.

IR spectroscopic studies were performed on a Spectrum Two FT-IR spectrometer (Perkin Elmer) in a cuvette made of zinc selenide with a thickness of $0.1036 \mathrm{~mm}$ using the program Spectrumv.10.03.06

\section{Results and Discussion}

It is known that during operation in ICE the motor oil undergoes significant changes in both chemical composition and operational properties $[1,10]$. It was found (Table 1) that used semi-synthetic motor oil is characterized by the lower viscosity and viscosity index, compared with those values of original oil. This change is explained by the fact that during the diesel engine operation in different modes under various mechanical and thermal loads a certain amount of diesel fuel, which has not burned in the engine, passes into the motor oil and dilutes it. This is confirmed by a decrease in the oil flash point due to the presence of diesel residues. Moreover, the group hydrocarbon composition of USSO is changed, which is confirmed by changes in the refractive index. At the same time, the used oil Castrol 10W-40 is characterized by a higher value of water content and mechanical impurities than the original oil, which indicates the wear of the cylinder-piston group parts during ICE operation under different thermal loads. The coking ability of the oil increases, which is obviously also the result of changes in group composition. However, the most important defective indicator of oil aging is the value of the acid number, which increases as well. As a result, the oil acquires aggressive properties to metal parts of the engine, which will lead to chemical destruction of their surface.

Table 1

Physico-chemical characteristics of original and used Castrol 10W-40

\begin{tabular}{|l|c|c|}
\hline \multicolumn{1}{|c|}{ Index } & Original oil & Used oil \\
\hline Viscosity, $\mathrm{mm}^{2} / \mathrm{s}:$ & & \\
$-\quad$ at $323 \mathrm{~K}, v_{50}$ & 62.61 & 84.86 \\
$-\quad$ at $373 \mathrm{~K}, v_{100}$ & 12.46 & 11.97 \\
$-\quad v_{50} / v_{100}$ & 5.00 & 7.09 \\
\hline Viscosity index & 120 & 60 \\
\hline Density, $\mathrm{kg} / \mathrm{m}^{3}$ & 863.0 & 879.7 \\
\hline Water content, \% & 0.06 & 0.15 \\
\hline Mechanical impurities content, \% & 0.63 & 1.24 \\
\hline Coking ability, \% & 0.73 & 1.55 \\
\hline Refractive index, $\mathrm{n}_{\mathrm{D}}{ }^{20}$ & 1.4692 & 1.4806 \\
\hline Freezing point, $\mathrm{K}$ & $<253$ & 253.5 \\
\hline Flash point $(\mathrm{open}$ cup), $\mathrm{K}$ & 490 & 474 \\
\hline Acid number, $\mathrm{mg} \mathrm{KOH} / \mathrm{g}$ & 1.54 & 2.25 \\
\hline
\end{tabular}


The results of original and used Castrol 10W-40 thermal studies

\begin{tabular}{|c|c|c|c|c|}
\hline \multirow{2}{*}{ Sample } & Stage & Temperature range, $\mathrm{K}$ & Weight loss, wt \% & $\begin{array}{c}\text { Maximum of } \\
\text { exothermic effect, } \mathrm{K}\end{array}$ \\
\hline \multirow{3}{*}{ Original oil } & I & $293-423$ & 0.20 & - \\
\cline { 2 - 5 } & II & $423-683$ & 90.10 & 607 \\
\cline { 2 - 5 } & III & $683-823$ & 6.07 & 719 \\
\cline { 2 - 5 } & I & $293-408$ & 0.70 & 594 \\
\cline { 2 - 5 } & II & $408-639$ & 65.13 & 693 \\
\cline { 2 - 5 } & III & $639-703$ & 5.89 & 729 \\
\hline
\end{tabular}

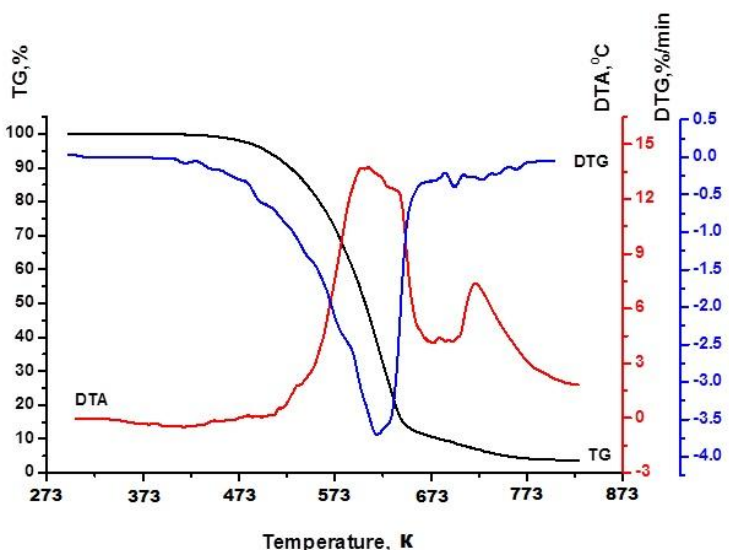

Fig. 1. Thermogram of original oil Castrol 10W-40

It is known that the motor oil used in ICE is supplied by an oil pump to all important lightly and heavily loaded tribological connections of the cylinder-piston group for their lubrication, cooling and washing of wear products. At the same time, the oil operates in different temperature zones of the internal combustion engine, in particular, in high temperature zones $(573-1773 \mathrm{~K})$ on the cylinder walls $[3,8]$. At such high temperatures, the oil undergoes significant thermal transformations leading to the loss of its weight. That is why, to determine the thermal stability and the value of weight loss the thermo-derivatographic studies should be carried out before and after oil operation in a diesel engine.

According to the results of thermo-gravimetric (TG), differential thermo-gravimetric (DTG) and differential thermal (DTA) analyses, the thermolysis of original and used semi-synthetic motor oil Castrol 10W40 occurs during three and four stages, respectively (Table 2, Figs. 1 and 2).

Thermolysis of original oil Castrol 10W-40 took place over three stages (Table 2). The first stage occurs in the temperature range of 293-423 K. During this stage there is a slight weight loss of the sample, which corresponds to the release of moisture. A shallow endothermic effect appears on the DTA curve (Fig. 1) in the above temperature range.

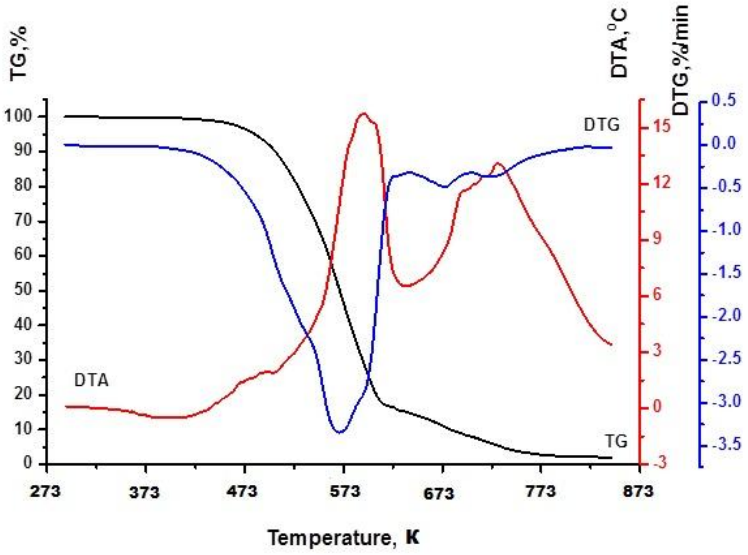

Fig. 2. Thermogram of used oil Castrol 10W-40

At the second stage, which occurs in the temperature range of $423-683 \mathrm{~K}$ and is accompanied by intense weight loss $(90.10 \%)$ of the sample, there is a thermo-oxidative destruction of the oil components, which ends with the combustion of the destruction residues. On the DTA curve (Fig. 1) in the above temperature range there is a bright exothermic effect with a maximum at $607 \mathrm{~K}$.

At the third stage, which occurs in the temperature range of $683-823 \mathrm{~K}$, the pyrolytic residue of the sample is burned. This process is accompanied by a clear exothermic effect on the DTA curve with a maximum at $719 \mathrm{~K}$

Unlike the original semi-synthetic motor oil, the thermolysis of used Castrol 10W-40 (Fig. 2) takes place during four stages.

At the first stage, which occurs in the temperature range of $293-408 \mathrm{~K}$, there is a release of moisture partially presented in the sample. During this process, there is a slight loss of sample weight and the appearance of an endothermic effect on the DTA curve (Fig. 2).

The second stage of USSO thermolysis occurs in the temperature range of 408-639 K. This stage corresponds to the intensive weight loss of the sample $(85.13 \%)$ and the appearance of a bright exothermic effect on the DTA curve, with a maximum at $594 \mathrm{~K}$. During this stage the thermo- 
oxidative destruction of the sample occurs, which ends with the combustion of destruction products. It should be noted that the USSO sample has less thermal stability, compared with the sample of the original oil. The thermal oxidative destruction of USSO begins at $408 \mathrm{~K}$ (versus $423 \mathrm{~K}$ for original oil), i.e. it shifts to the region of lower temperatures. We also observe an intensive weight loss of USSO (Fig. 3). The maximum of exothermic effect of the second stage (Fig. 4) shifts to the region of lower temperatures $(594 \mathrm{~K}$ versus $607 \mathrm{~K}$ for original oil). The lower thermal stability of USSO can be explained by a decrease in the concentration of additives which partially inhibit the thermal oxidation process.

The third and fourth stages of thermolysis occur in the temperature range of $639-703 \mathrm{~K}$ and $703-823 \mathrm{~K}$, respectively. These two stages are accompanied by a gradual weight loss of the oil sample and the appearance of sharp exothermic effects on the DTA curves (Fig. 4). At these stages the burning of pyrolytic residue takes place. The maximum of exothermic effect of the forth stage is shifted to the region of high temperatures $(729 \mathrm{~K})$, probably due to the combustion of the densest oil structures formed during its operation in the diesel engine.

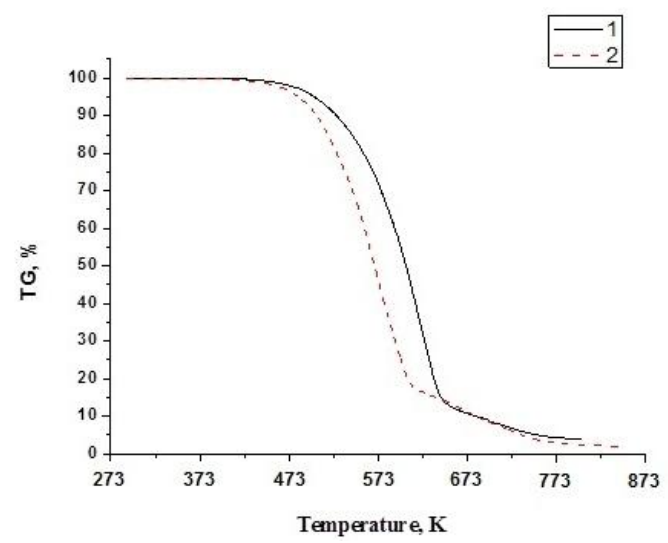

Fig. 3. TG curves of original (1) and used (2) Castrol 10W-40
It is known that commercial motor oils contain inorganic components that are the part of the additives introduced into the oil to improve its performance. During the active use of oil in the internal combustion engine additives become depleted and destroyed; they contaminate the oil with their decomposition products. According to additives depletion we can reveal the durability of the engine and the service life of lubricating oils [11]. Therefore, analyzing the content of metals (indicators of ICE parts mechanical wear) and patterns of changes in the elemental composition of the oil, we can effectively control the properties of motor oils and diagnose faulty tribological components of the engine.

Today, car manufacturers, namely Detroit Diesel, Caterpillar, Cummins and others, strictly regulate the metal content in motor oils. Thus, the above car manufacturers recommend to replace the engine oil with a new one when the content of such metals as iron, chromium, lead, copper, tin, aluminum, sodium, potassium and non-metals (silicon, boron) in the working oil exceeds the allowable one (15-150 ppm) [11, 12]. Excessive increase in the content of metals is one of the reasons for motor oil replacement.

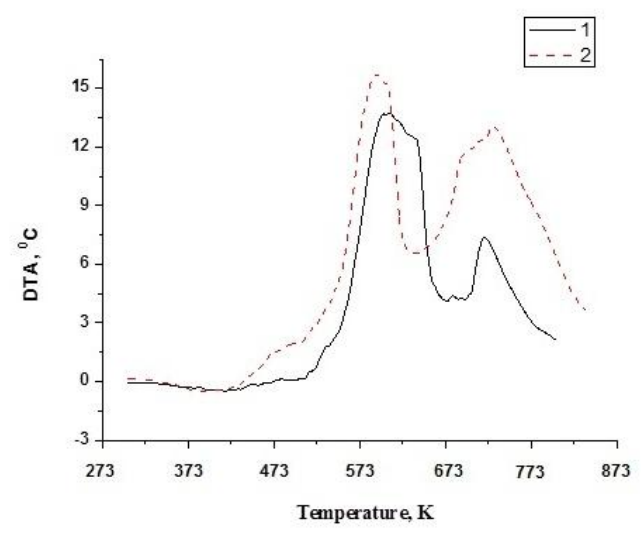

Fig. 4. DTA curves of original (1) and used (2) Castrol 10W-40

Table 3

Elemental composition of the inorganic part of the semi-synthetic motor oil Castrol 10W-40

\begin{tabular}{|c|c|c|}
\hline \multirow{2}{*}{ Element } & \multicolumn{2}{|c|}{ Content, \% } \\
\cline { 2 - 3 } & Original oil & Used oil \\
\hline $\mathrm{Si}$ & $0.950 \pm 0.029$ & $1.141 \pm 0.032$ \\
\hline $\mathrm{P}$ & $4.428 \pm 0.022$ & $4.834 \pm 0.023$ \\
\hline $\mathrm{S}$ & $3.959 \pm 0.018$ & $4.193 \pm 0.017$ \\
\hline $\mathrm{Ca}$ & $41.800 \pm 0.091$ & $36.694 \pm 0.098$ \\
\hline $\mathrm{Cr}$ & - & $0.058 \pm 0.011$ \\
\hline $\mathrm{Fe}$ & $0.106 \pm 0.006$ & $0.544 \pm 0.010$ \\
\hline $\mathrm{Cu}$ & $0.011 \pm 0.004$ & $0.223 \pm 0.005$ \\
\hline $\mathrm{Zn}$ & $14.626 \pm 0.053$ & $18.582 \pm 0.059$ \\
\hline $\mathrm{Mo}$ & $0.719 \pm 0.005$ & $0.240 \pm 0.003$ \\
\hline $\mathrm{Pb}$ & - & $0.035 \pm 0.002$ \\
\hline
\end{tabular}


To study the elemental composition of the original and used motor oils we used X-ray fluorescence analysis (X-ray diffraction), which is one of the leading, selective and rapid methods for determining the elemental composition of petroleum products. The experimental results are presented in Table 3.

Analyzing the obtained results (Table 3) we can state the following [13]:

- phosphorus, sulfur, and zinc indicate the presence of antioxidant and anti-wear additives in the oil (for example, DF-11, LANI-317, Anti Wear, ZDDP, etc.);

- calcium, chromium, iron and copper reveal the presence of detergent-dispersing additives (for example, SC-3);

- molybdenum and lead characterize the presence of friction additives (for example, $\mathrm{MoS}_{2}$, lead naphthenate), as well as corrosion inhibitors and remetallizers.

The change in the content of above-mentioned metals indicates the presence of wear elements of the ICE cylinder-piston group, as well as the ingress of unwanted mechanical contaminants into the oil. The available information on the presence of metals in the used oil allows us to assess the technical condition of the engine [14, 15].

The above-identified metals (iron, molybdenum, lead) contained in USSO, are mandatory components of metal alloys of parts of any engine. During its operation, microscopic metal particles are erased from the work surfaces and get into the engine oil. Thus, iron is the main structural material of the most important parts: cylinder block, cylinder head, valves, crankshafts and camshafts, connecting rods, piston pins, oil pump. The increased content of iron in the used oil usually indicates the wear of one or more engine components. Titanium, which is characterized by its strength, is the main element of the alloy used for turbines, springs and valves manufacture. Molybdenum, as a wear-resistant metal, is most commonly found in piston rings and rolling bearings. Lead is often used for babbitt based coatings, as well as for doping alloys used for connecting rods and bearing pad of crankshaft. The lead content in the used oil

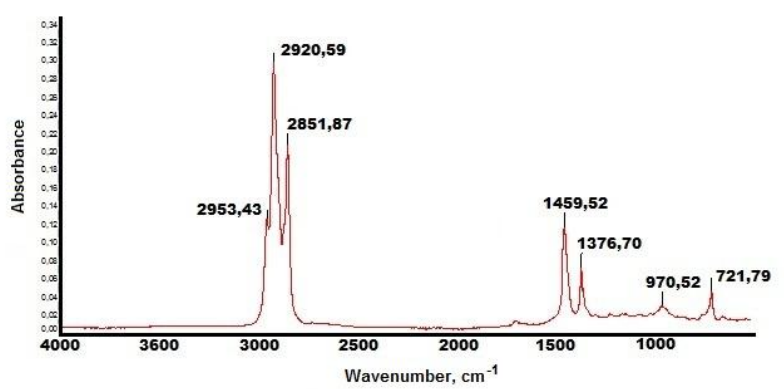

Fig. 5. IR spectrum of the original semi-synthetic motor oil Castrol 10W-40 indicates the wear of the crankshaft bearings, etc. The decrease in calcium content in USSO indicates the depletion of detergent-dispersing additives or corrosion inhibitors. Phosphorus and sulfur in small quantities allow the surfaces of metal parts to be chemically inert. The increase in their content indicates the wear of the metal surfaces.

Another reason for the increase in inorganic components content is the addition of a new portion of oil between its changes. Typically, this is done for engines with significant mileage (approaching the repair period) in order to compensate the oil losses from burning and leakage. In this case, only the organic part of the oil burns out, and inorganic components accumulate in the oil, which circulates in the lubrication system of ICE.

When using oil, the aging products (alcohols, aldehydes, ketones, organic acids, etc.) are formed and accumulated. To detect these compounds in USSO, IR spectroscopic studies of the original and used semisynthetic motor oil Castrol 10W-40 were performed (Figs. 5 and 6).

Analyzing the IR spectra of the original and spent Castrol 10W-40 oil, we can note their similarities, as well as the differences.

In the IR spectrum of the original oil (Fig. 5) the paraffin-naphthenic hydrocarbons were identified by stretching vibrations of the $\mathrm{C}-\mathrm{H}$ bond in the absorption region at $2800-3000 \mathrm{~cm}^{-1}$, deformation vibrations of $\mathrm{C}-\mathrm{H}$ bonds in methyl and methylene groups at $1459 \mathrm{~cm}^{-1}$ and symmetrical deformation vibrations of methyl groups at $1376 \mathrm{~cm}^{-1}$ [16]. In the region of the absorption bands at $721 \mathrm{~cm}^{-1}$, a doublet of medium intensity was detected, which corresponds to the pendulum vibrations of the $\left(\mathrm{CH}_{2}\right)_{\mathrm{n}}$ chains. Absorption bands in the region of $800-1100 \mathrm{~cm}^{-1}$ indicate the presence of naphthenic hydrocarbons. At the same time, the absorption band of low intensity at $970 \mathrm{~cm}^{-1}$ indicates the presence of an antioxidant additive (zinc dialkyldithiophosphate) in the origin oil. A viscous additive (polymethyl methacrylate) was detected by low-intensity absorption bands at 1160 and $1740 \mathrm{~cm}^{-1}$ [16].

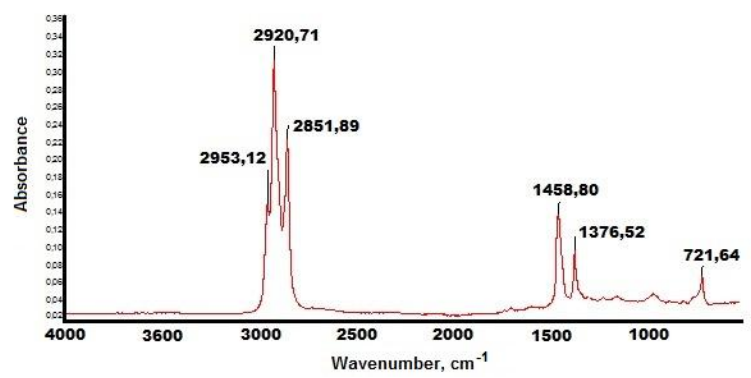

Fig. 6. IR spectrum of the used semi-synthetic motor oil Castrol 10W-40 
Analyzing the IR spectrum of USSO (Fig. 6), in addition to the above-described absorption bands we detected some aging products with characteristic $\mathrm{C}=\mathrm{O}$ groups in the absorption range of $1730-1690 \mathrm{~cm}^{-1}$. Carboxylic acids in the used oil are identified by the absorption bands of the carboxyl group in the range of $1720-1680 \mathrm{~cm}^{-1}$, which are not observed in the IR spectrum of the original oil. This confirms the increase in the value of the USSO acid number (Table 1). The presence of esters as oil aging products is confirmed by the absorption bands of the aliphatic esters $\mathrm{C}=\mathrm{O}$ group in the region of $1740-1730 \mathrm{~cm}^{-1}$, as well as in the region of $1235-1225 \mathrm{~cm}^{-1}$, which is characteristic of stretching vibrations of $\mathrm{C}-\mathrm{O}$ bond. The $\mathrm{C}=\mathrm{O}$ carbonyl group, contained in aldehydes, acids and alcohols, is confirmed by the absorption bands in the regions of 1725-1620 and $1165-1125 \mathrm{~cm}^{-1}$, which is characteristic of the deformation vibrations of the $\mathrm{CO}$ group. These bands are not observed in the IR spectrum of the original oil [17, 18]. An adsorption band in the region of $1705-1740 \mathrm{~cm}^{-1}$ should be noted in both spectra. To our mind, this band may indicate the presence of diesters - the synthetic part of semi-synthetic motor oil Castrol 10W-40 [16].

\section{Conclusions}

The change of operational properties of original and used semi-synthetic motor oil Castrol 10W-40 for diesel engines was studied. By means of derivatography, it was found that used oil Castrol 10W-40 has a lower thermal stability in comparison with the original oil. It was established that the composition of the inorganic part of motor oils changes during ICE operation due to the depletion of additives, ingress of wear debris into the oil, as well as adding the oil in the crankcase to maintain the required operating level. IR spectroscopy confirmed the formation of oxygen-containing "aging" products in the process of oils long-term use in a diesel internal combustion engine of a commercial vehicle.

\section{References}

[1] Hrynyshyn O., Korchak B., Chervinskyy T., Kochubei V.: Chem. Chem. Technol., 2017, 11, 387. https://doi.org/10.23939/chcht11.03.387

[2] Korchak B., Hrynyshyn O., Chervinskyy T., Polyuzhin I.: Chem. Chem. Technol., 2018, 12, 365.

https://doi.org/10.23939/chcht12.03.365
[3] Korchak B., Hrynyshyn O., Chervinskyy T.: Sci. Bull. UNFU, 2017, 27, 93. https://doi.org/10.15421/402706

¡4] Korchak B., Hrynyshyn O., Chervinskyy T. et al.: Sci. Bull. UNFU, 2020, 30, 127. https://doi.org/10.36930/40300122

¡5] Korchak B., Grynyshyn O., Chervinskyy T. et al.: Chem. Chem. Technol., 2020, 14, 129. https://doi.org/10.23939/chcht14.01.129

[6] Dominguez-Rosado E., Pichtel J.: Proceed. Indiana Acad. Sci., 2003, 112, 109.

[7] Sánchez-Alvarracín C., Criollo-Bravo J., Albuja-Arias D. et al.: Recycling, 2021, 6, 10. https:// doi.org/10.3390/recycling6010010

[8] Tripathi A., Vinu R.: Lubricants, 2015, 3, 54.

https://doi.org/10.3390/lubricants3010054

[9] Khaziev A., Sugatov N., Petukhov M.: Transport. Transportnye Sooruzhenia. Ekologia, 2014, $2,97$.

[10] Liang Z., Chen L., Alam M. et al.: Fuel, 2018, 220, 792. https://doi.org/10.1016/j.fuel.2017.11.142

[11] Karaulov A., Khudolii N.: Avtomobilnye Masla. Motornye i Transportnye. Assortiment i Primenenie. Raduga, Kyiv 2000.

[12] Pelitli V., Doğan Ö., Köroğlu H.: Global J. Environ. Sci.

Manage., 2017, 3, 11.

https://doi.org/10.22034/gjesm.2017.03.01.002

[13] Nikolakopoulos P., Mavroudis S., Zavos A.: Lubricants, 2018, 6, 90. https://doi.org/10.3390/lubricants6040090

[14] Stout S., Litman E., Blue D.: Environ. Forensics, 2018, 19, 191. https://doi.org/10.1080/15275922.2018.1474288

[15] Evans J.: Techn. Bull, 2010, 47, 1.

http://wearcheck.com/virtual_directories/Literature/Techdoc/WZA0 47.pdf

[16] Rudniev V., Klimchuk A., Nardid L. et al.: Teoria i Praktyka

Sudovoi Espertyzy i Kriminalistiky, 2017, 17, 266.

[17]

http://sites.science.oregonstate.edu/ gablek/CH335/Chapter10/IR.ht $\mathrm{m}$

[18] http://www3.uma.pt/jrodrigues/disciplinas/QINO-

II/Teorica/IR.pdf

Received: October 07, 2019 / Revised: February 18, 2020 / Accepted: June 20, 2020

\section{ДОСЛІДЖЕННЯ ВЛАСТИВОСТЕЙ НАПІВСИНТЕТИЧНОЇ МОТОРНОЇ ОЛИВИ CASTROL 10W-40 ПІСЛЯ ВИКОРИСТАННЯ У ДИЗЕЛЬНОМУ ДВИГУНІ}

\begin{abstract}
Анотація. Проведені дослідження експлуатайійних властивостей нової та відпрацьованої напівсинтетичної моторної оливи Castrol 10W-40 для дизельних двигунів автомобілів комерційного класу використання. Наведені результати дериватографічного та ІЧ-спектроскопічного досліджень. За допомогою рентгенофлуоресиентного аналізу встановлено склад неорганічної частини досліджуваних напівсинтетичних олив.
\end{abstract}

Ключові слова: напівсинтетична моторна олива, відпрачьована олива, термічний розклад, старіння оливи, рентгенофлуоресиентний аналіз, IЧ-спектри. 